\title{
「水質污濁研究」次号（Vol.7 No.2）の予定目次
}

\section{〈特集〉}

これからの水質保全について

〈論文〉

銅イオンによる活性污泥中の $\beta$-galactosidase 拉よび dehydrogenases 活性の阻害について

片山壮子

塩素処理による有機化合物の全有機塩素化合物

( TOCl) 生成特性

相 沢 貴 子他

\section{$\langle ノ-ト\rangle$}

三河湾に扣ける懸濁粒子の分布

.近 藤 正 夫他

実験廃液処理施設での処理水水質のパターン表示

岩 崎 隆 昌他

底質中に拈ける排泄物污濁指標としてのコプロスタノールについて

坚 玉 剛 則

本誌 Vol. 6 No.6 亿揭載の論文「加古川水系の 水質変動解析」に下記の誤りがございました。

ここに訂正し，謹しんで扔詫び申しあげます。

\section{p.50右欄 $23 \sim 24$ 行目}

（誤）抒よび $\mathrm{pH}$ も低く，逆に $\mathrm{DO}$ と $\mathrm{DO}_{\mathrm{sat}}$.とは高 い。清澄な地点であることをうかがわせる。 BOD, COD

（正）,DO 拈よび $\mathrm{DO}_{\mathrm{sat}}$.の各項目では，K3と $\mathrm{K} 4$ と の間に有意な濃度差がみられ，支流の篠山川 の影響が
本誌Vol. 6 No.6 に揭載の「第18回水質污濁学 会開催案内」に下記の誤りがございました。

ここに訂正し，謹しんで报詫び申し上げます。

講演番号 222

(誤) キレート物質存在下での底質からの好気的溶 出条件

一溶解度積からの検討一

（正）キレート物質存在下での底質からの好気的溶 出 一条件溶解度積からの検討一 